\title{
Reducing copper toxicity by drinking coffee
}

\author{
H. Djati Utomo \\ UTM, Department of Environmental Engineering, Johor, Malaysia
}

\begin{abstract}
Copper contamination in drinking water is not a new issue in today's world. Various modern industries use copper for their raw materials and discharge copper by-products into the watercourse. Current water treatment technology is not a guarantee for providing safe drinking water required by humans. Although copper is one of the essential nutrients required by the human body for both physical and mental health, an excessive copper concentration in the human body becomes a toxic threat. Drinking coffee habitually may be helpful in reducing copper concentrations, which might lead to a reduction in copper toxicity. This experimental study, using copper-ion selective electrode (Cu-ISE), lowered copper concentrations due to the availability of copper binding ligands found in coffee solution. The copper electrodes were calibrated thoroughly using ethylenediamine (en) standard buffer solution before being used for determining free and bound copper ions in coffee solution.
\end{abstract}

Keywords: copper, Cu-ISE, coffee, copper binding ligands, en, toxicity.

\section{Introduction}

Water pollution due to toxic heavy metals contamination is a major issue for today's environment. Various trace metals such as lead, mercury, zinc, copper, nickel and cadmium are released to the environment as a result of human activities. Modern uses of these metals include the production of alloys, photography, paints and dyes, pesticides (e.g. copper oxychloride), textiles, electrical wiring and electroplating. Judd et al. [1] estimated that the production of printed wiring board (PWB) produced about $60 \%$ of the soluble metals disposed of into wastewaters. Copper is extremely toxic to aquatic biota exhibiting an adverse impact at concentrations as low as 15 to $30 \mathrm{nmol} \mathrm{L}^{-1}$ (Davey et al. [2], Gillespie and Vaccaro [3]) Concerns about trace metals 
primarily result from their potential toxicity, persistence and tendency to become concentrated in food chains (Brierley et al. [4], Holan et al. [5]).

Although some trace metals have a key role in the functioning of metalloprotein enzymes (Stumm and Morgan [6]), when a metal ion such as copper, exceeds its requirement by an organism there is the potential for toxic effects. Current US-Canadian Recommended Dietary Allowance (RDA) for copper is $9 \mathrm{mg} / \mathrm{d}$ for adults, with a tolerable upper intake level (UL) of $10 \mathrm{mg} / \mathrm{d}$ for adults (Institute of Medicine [7]). Chronic copper toxicity, as an effect of detrimental symptoms, can result in liver disease and severe neurological defects (UriuAdams and Keen [8], Davanzo et al. [9], Srivastava et al. [10], World Health Organization [11]). Acute copper toxicity can result in a number of pathologies and, in severe cases, death. It can result from the ingestion of copper contaminated beverages including water or the accidental or deliberate ingestion of high quantities of copper salts (Uriu-Adams and Keen [8]). Unfortunately the mechanism underlying the acute copper toxicity effects in humans is not well understood.

Drinking coffee not only gives much-needed lift in the morning but it can also reduce the copper concentration in the water used for preparing the coffee as an improvement of drinking water quality.

This paper deals with the health benefits of drinking coffee as a result of copper binding ligands released from soluble coffee. Tannin-containing materials such as coffee or tea contain metal-binding polyhydroxy-polyphenol functional groups (Bailey et al. [12]). Tannic acid is a phenolic material considered responsible for the tannin flavour of beverages such as tea or coffee. Tannic acid consists of a glucose core, which covalently links to $3-5$ gallic acid residues through ester bonds. In addition, each gallic acid residue can covalently link to other gallic acid units as shown in Figure 1.
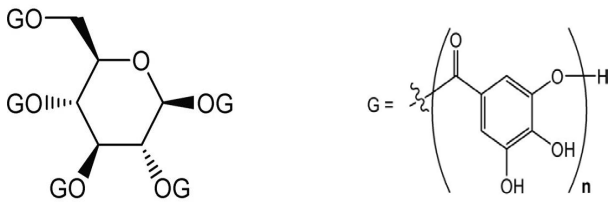

Figure 1: $\quad$ Molecular structure of tannic acid (Liu [26]).

\section{$2 \mathrm{Cu}$-ISE as a method for determining copper binding organic ligands in coffee solution}

A number of analytical approaches have been developed to measure metal speciation in natural waters. Metal ion-selective electrodes (ISE) are particularly useful for toxicity studies and for the determination of the complexation capacity of freshwater. ISEs have been used to directly measure ambient free metal concentrations in river or lake water, but they are in general limited by their sensitivity and selectivity (Sunda and Hanson [13], Camusson et al. [14], Xue 
and Sunda [15]). The copper ion-selective electrode (Cu-ISE) has insufficient sensitivity for reliable measurement at the low ambient $\mathrm{Cu}$ concentrations in most natural waters. In addition, it cannot be used in seawater because of chloride interference (Westall [16]). Here the importance of calibration method can be the determinant factor before being used as a reliable method for characterising between free and bound copper ion (Chau and Chan [17], Ramamoorty and Kushner [18]). The Cu-ISE has been applied to the determination of reaction stoichiometries and metal-ligand binding strengths (Rifkin et al. [19], Berminham-McDonogh et al. [20].

The interaction between $\mathrm{Cu}^{2+}$-binding organic compounds in coffee solutions and $\mathrm{Cu}^{2+}$ was examined by titrating a sample of solution with known additions of $\mathrm{Cu}^{2+}$, measuring the free $\left[\mathrm{Cu}^{2+}\right]$ using the $\mathrm{Cu}$-ISE as used for titrations of $\mathrm{Cu}^{2+}$ in raw and treated potable waters (Luo [21], Sanders et al. [22]).

\section{Experimental}

\subsection{Preparation of copper and coffee solutions}

$6.36 \mathrm{~mL}$ of Copper (II) Nitrate AAS Standards (APS Ajax Finechem, $1000 \mathrm{ppm}$ in $0.5 \% \mathrm{HNO}_{3}$ ) were added to a $100 \mathrm{~mL}$ volumetric flask and made up with deionised water (Millipore Milli-Q System known as Milli-Q water) to make $\mathrm{Cu}^{2+}$ standard solution $\left(10^{-3} \mathrm{~mol} \mathrm{~L}^{-1}\right)$. Dilution method was used to prepare the remaining stock solutions $\left(10^{-4} \mathrm{~mol} \mathrm{~L}^{-1}, 10^{-5} \mathrm{~mol} \mathrm{~L}^{-1}\right.$, and $\left.10^{-6} \mathrm{~mol} \mathrm{~L}^{-1}\right)$. All of these stock solutions were acidified to $0.1 \% \mathrm{v} / \mathrm{v}$ with $\mathrm{HNO}_{3}$ to minimize adsorptive loss of $\mathrm{Cu}^{2+}$ and stored in polyethylene bottles. They were freshly prepared every 1-2 weeks.

Coffee solutions were prepared by soaking $10.0 \mathrm{~g}$ and $20.0 \mathrm{~g}$ of commercial coffee ground (Blue Mountain variety) in $1000 \mathrm{~mL}$ Milli-Q water overnight at room temperature. The solid phase was removed by filtering the coffee suspension through Whatman 114 filter paper before adding $10.1 \mathrm{~g}$ of $\mathrm{KNO}_{3}$ to make a final ionic strength $\mathrm{I}=0.1 \mathrm{~mol} \mathrm{~L}^{-1}$. After the $\mathrm{KNO}_{3}$ was dissolved the solution was divided into $50 \mathrm{~mL}$ portions in beakers. Different concentrations of $\mathrm{Cu}^{2+}$ standard solution were then added to each solution aliquot to produce final concentrations of added $\mathrm{Cu}^{2+}$ ranging from $10^{-3} \mathrm{~mol} \mathrm{~L}^{-1}$ to $0.5 \times 10^{-6} \mathrm{~mol} \mathrm{~L}^{-1}$. The $\mathrm{pH}$ of each solution was adjusted (with either $0.1 \mathrm{~mol} \mathrm{~L}^{-1} \mathrm{HCl}$ or $2 \mathrm{~mol} \mathrm{~L}^{-1}$ $\mathrm{NaOH}$ ) back to the $\mathrm{pH}$ of 5.03 , which was observed before addition of $\mathrm{Cu}^{2+}$ before being equilibrated overnight.

\subsection{Preparation of apparatus}

The $94298 \mathrm{~N}$ Orion cupric electrode and 900200 Orion double junction reference electrode were stored in Milli-Q water while not in use. Before measurement, the shiny surface of the cupric electrode was buffed gently (30s) with Orion alumina polishing strips. The electrode was then rinsed vigorously with Milli-Q water and placed in $0.025 \mathrm{~mol} \mathrm{~L}^{-1} \mathrm{H}_{2} \mathrm{SO}_{4}$ for $10 \mathrm{~min}$, which served to clean the electrode (Blaedel and Dinwiddie [23]). Since the slope of the Nernst equation is temperature-dependent, temperature is a factor that can affect the potential 
reading in a test solution. Thus in the present study, a measurement cell having a water jacket through which water from a constant temperature water bath was pumped to keep the temperature of the sample as constant as possible through all the measurements. The temperature variation of the water bath was $\pm 0.2{ }^{\circ} \mathrm{C}$. In addition, the size and rotation speed of the magnetic stirrer bar, and the distances of the electrodes from each other and the stirrer, were kept constant throughout all the experiments. Between two measurements, the electrodes, stirrer bar and inside of the cell were vigorously rinsed with $0.025 \mathrm{~mol} \mathrm{~L}^{-1} \mathrm{H}_{2} \mathrm{SO}_{4}$ and soaked in Milli-Q water. Potentials were measured using an Orion Expandable Ion Analyzer EA920. A glass pH electrode was also inserted into the solution to measure solution $\mathrm{pH}$. The EA920 has two electrode channels so it was possible to measure both $\mathrm{pH}$ and the potential of the $\mathrm{Cu}$-ISE cell with a single instrument.

\subsection{Calibration of copper electrodes and ethylenediamine (en) standard buffer solution}

The calibration of the copper electrode could be conducted at very low copper concentration (as low as $10^{-19} \mathrm{~mol} / \mathrm{L}$ ) using copper ion buffer reagent following Avdeef's method (Avdeef et al. [24]). With the method the curves can possess $>$ $99 \%$ ideal Nernstian slope (theoretically $29.58 \mathrm{mV} / \mathrm{pCu}$ at $25^{\circ} \mathrm{C}$ ). The value of $\mathrm{pCu}$ in these solutions can be calculated by solving the equilibrium eqns (1) using a macro procedure written in Visual Basic (Djati Utomo [25]). The $\mathrm{Cu}^{2+} /$ en system involves the following reactions:

$$
\begin{aligned}
& \mathrm{H}^{+}+\mathrm{en} \rightleftharpoons \mathrm{Hen}^{+} \quad \mathrm{K}_{1}{ }^{\mathrm{H}}=\frac{\left[\mathrm{Hen}^{+}\right]}{\left[\mathrm{H}^{+}\right][\mathrm{en}]} \\
& \mathrm{H}^{+}+\mathrm{Hen}^{+} \rightleftharpoons \mathrm{H}_{2} \mathrm{en}^{2+} \quad \mathrm{K}_{2}{ }^{H}=\frac{\left[\mathrm{H}_{2} \mathrm{en}^{2+}\right]}{\left[\mathrm{H}^{+}\right]\left[\mathrm{Hen}^{+}\right]} \\
& \mathrm{Cu}^{2+}+e n \rightleftharpoons \mathrm{Cu}(e n)^{2+} \quad K_{1}=\frac{\left[\mathrm{Cu}(e n)^{2+}\right]}{\left[\mathrm{Cu}^{2+}\right][e n]} \\
& \mathrm{Cu}(\mathrm{en})^{2+}+e n \rightleftharpoons \mathrm{Cu}(\mathrm{en})_{2}{ }^{2+} \quad \mathrm{K}_{2}=\frac{\left[\mathrm{Cu}(\mathrm{en})_{2}{ }^{2+}\right]}{\left[\mathrm{Cu}(\mathrm{en})^{2+}\right][e n]}
\end{aligned}
$$

The equilibrium constants $\left(\log \mathrm{K}_{1}=10.512\right.$ and $\left.\mathrm{K}_{2}=9.034\right)$ and protonation constants for en $\left(\log \mathrm{K}_{1}{ }^{\mathrm{H}}=10.063\right.$ and $\left.\mathrm{K}_{2}{ }^{\mathrm{H}}=7.204\right)$ at an ionic strength $\mathrm{I}=0.1$ mol L ${ }^{-1}$ were reported by Avdeef et al. [24] and Djati Utomo [25] respectively. The new Avdeef's protonation constants for en were re-measured by Djati Utomo [25] to improve agreement between the $\mathrm{Cu}^{2+}$ en buffers and $\mathrm{Cu}^{2+}$ solutions.

\subsection{Measurement of $\mathrm{pCu}$ in coffee solutions using the $\mathrm{Cu}$-ISE}

Calibration of the ISE using $\mathrm{Cu}\left(\mathrm{NO}_{3}\right)_{2}$ and $\mathrm{Cu}^{2+}$-en standard solutions of known free $\left[\mathrm{Cu}^{2+}\right]$ was conducted before and after measuring the potential of the sample 
of coffee solutions. Both the $\mathrm{pH}$ and potential of the $\mathrm{Cu}$-ISE were measured for each coffee solution (after calibration of the $\mathrm{Cu}$-ISE).

\section{Results and discussion}

\subsection{Cu-ISE electrode calibration}

The electrode calibration was carried out using the $10^{-6}$ to $10^{-3} \mathrm{~mol} \mathrm{~L}^{-1}$ copper standard solutions, and the five $\mathrm{Cu}$-en metal ion buffer solutions having nominal $\mathrm{pH}$ values of 5, 6, 7, 8 and 9 respectively. A typical calibration curve obtained by plotting the measured potential against $\mathrm{pCu}$ is shown in figure 2 , with the corresponding data presented in table 1 . It is seen that the electrode response follows the expected linear Nernst over the $\mathrm{pCu}$ range used for calibration. The slope of the calibration was $-24.535 \mathrm{mV}$ (the ideal Nernst value of $-29.58 \mathrm{mV}$ at $\left.25^{\circ} \mathrm{C}\right)$. It is important to note that the data points for $\mathrm{Cu}\left(\mathrm{NO}_{3}\right)_{2}$ standards lie on the same line, within experimental error, as those for the $\mathrm{Cu}^{2+}$ en metal ion buffers.

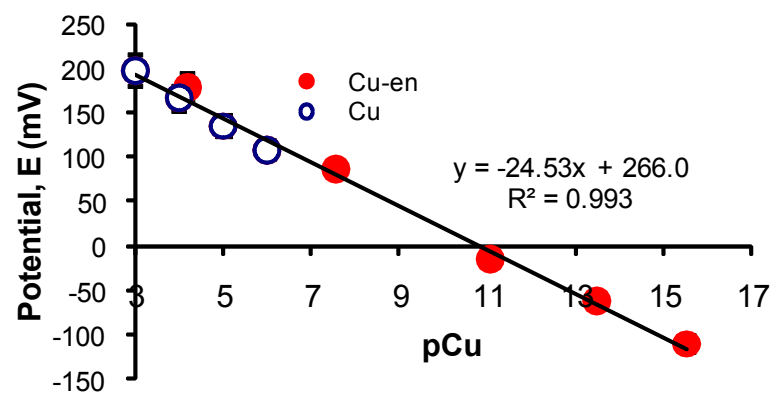

Figure 2: A typical Cu-ISE calibration used for coffee solution samples. The measured $\mathrm{Cu}$-ISE potential is shown as a function of $\mathrm{pCu}=-\log$ $\left[\mathrm{Cu}^{2+}\right]$, where $\left[\mathrm{Cu}^{2+}\right]$ is the calculated concentration of free $\mathrm{Cu}^{2+}$ in the $\mathrm{Cu}\left(\mathrm{NO}_{3}\right)_{2}$ (open circles) and $\mathrm{Cu}^{2+}$-en (solid circles) standard solutions.

\subsection{Copper binding ligands in coffee solutions}

Two different concentrations of coffee soluble sourced from 10 and $20 \mathrm{~g} \mathrm{~L}^{-1}$ of coffee grounds leached in Milli-Q water are presented in figure 3. The measured concentrations of free $\mathrm{Cu}^{2+}$ fall well below the 1:1 line as a result of $\mathrm{Cu}^{2+}$ binding by soluble ligands in the solution. In addition, the decrease in $\left[\mathrm{Cu}^{2+}\right]$ is greater for the $20 \mathrm{~g} \mathrm{~L}^{-1}$ solution than for the ones containing only $10 \mathrm{~g} \mathrm{~L}^{-1}$ in agreement with an expected higher concentration of soluble material in the former case. In figure 3 the curvature of the plot is changing in two different regions, i.e. near $\log \left[\mathrm{Cu}^{2+}\right] \approx 3$ and 5 . This might be explained from the complexity of organic 
materials in coffee soluble. It was very unlikely that there is a single functional group responsible for $\mathrm{Cu}^{2+}$ binding. It is probable that the observed behaviour is due to many functional groups whose $\mathrm{Cu}^{2+}$-binding properties differ slightly from each other. However, it is difficult to be certain about this because of the lack of data points. It was difficult to predict in advance which values of $\left[\mathrm{Cu}^{2+}\right]_{\mathrm{T}}$ to choose in constructing the curves due to the drift of $\mathrm{Cu}$-ISE (each sample reading took $30-45 \mathrm{~min}$ ).

Table 1: $\quad \mathrm{pH}$ and $\mathrm{pCu}$ of $\mathrm{Cu}^{2+}$ standard solutions and typical measured potential for $\mathrm{Cu}-\mathrm{ISE}$ calibration at $25 \pm 0.1^{\circ} \mathrm{C}$.

\begin{tabular}{|c|c|c|c|}
\hline Calibration standards & $\mathrm{pH}$ & $\mathrm{pCu}$ & Potential / $\mathrm{mV}$ \\
\hline $10^{-3} \mathrm{~mol} \mathrm{~L}^{-1} \mathrm{Cu}^{2+}$ solution & 2.00 & 3.00 & 196.5 \\
\hline $10^{-4} \mathrm{~mol} \mathrm{~L}^{-1} \mathrm{Cu}^{2+}$ solution & 2.07 & 4.00 & 165.5 \\
\hline $10^{-5} \mathrm{~mol} \mathrm{~L}^{-1} \mathrm{Cu}^{2+}$ solution & 2.02 & 5.00 & 134.6 \\
\hline $10^{-6} \mathrm{~mol} \mathrm{~L}^{-1} \mathrm{Cu}^{2+}$ solution & 2.03 & 6.00 & 107.5 \\
\hline Standard solution A & 5.20 & 4.18 & 178.6 \\
Standard solution B & 6.21 & 7.56 & 86.3 \\
Standard solution C & 7.21 & 11.05 & -15.0 \\
Standard solution D & 8.19 & 13.49 & -62.0 \\
Standard solution E & 9.22 & 15.53 & -110.2 \\
\hline
\end{tabular}

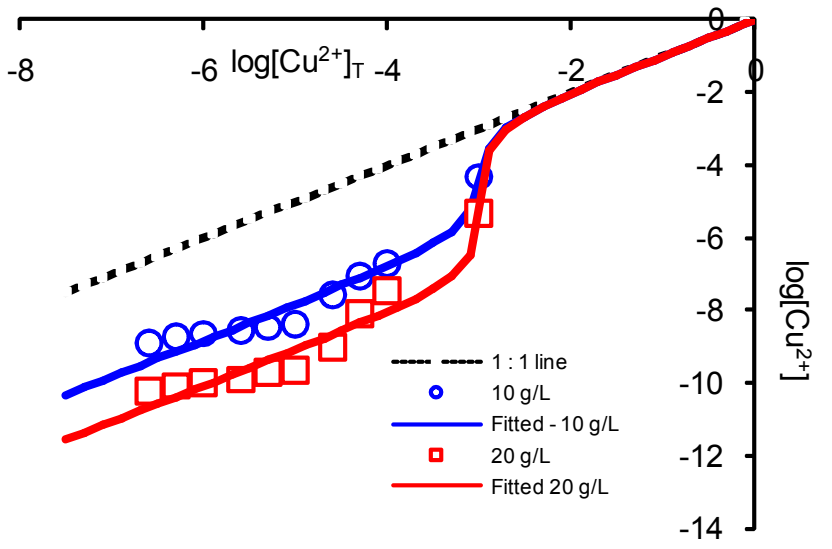

Figure 3: Results of Cu-ISE titration of coffee solution samples containing $10 \mathrm{~g} \mathrm{~L}^{-1}$ (upper, circles) and $20 \mathrm{~g} \mathrm{~L}^{-1}$ (lower, squares) of solid. The free $\mathrm{Cu}^{2+}$ concentrations calculated from the ISE calibration parameters are shown as a function of the total concentration of $\mathrm{Cu}^{2+}$ added to each sample aliquot. The dotted line shows the 1:1 relationship and the solid lines show the fitted results as described in the text. 


\section{Conclusions}

Organic materials that leached in coffee solution contain copper binding ligands. With a proper calibration the results from the experimental study using Cu-ISE showed the existence of the copper binding ligands in coffee solution. The higher $\mathrm{pCu}$ (as indicated by a lower potential reading in copper electrode of $\mathrm{Cu}$ ISE) means less free $\left[\mathrm{Cu}^{2+}\right]$ in coffee solution due to the binding mechanism to soluble organic ligands.

The habit of drinking coffee may helpful in reducing free excessive copper concentration found in the drinking water and may benefit to human health.

The Cu-ISE experiments were very time-consuming because of the slow equilibration, making it possible for changes to occur with time. Advanced electrochemical techniques such as anodic stripping voltammetry (ASV) and competitive ligand equilibration cathodic stripping voltammetry (CLE-CSV) might be very useful for furthering a fundamental study of complexing of metal ions by soluble coffee organic materials.

\section{Acknowledgements}

The author is grateful to receive a research grant from the Research Management Center-UTM (Vote: 77510) and also to the University of Otago for providing the University of Otago Postgraduate Publishing Award. The author also thanks Professor Keith A. Hunter for his help in developing a non-linear fitting macro procedure written in Visual Basic i.e. for obtaining the protonation constants $\mathrm{K}_{1}{ }^{\mathrm{H}}$ and $\mathrm{K}_{2}{ }^{\mathrm{H}}$ used for $\mathrm{Cu}$-ISE calibration.

\section{References}

[1] Judd, R. L., B. Fleet, et al. Waste reduction strategies for the printed wiring board industry, Final report to Department of Health Services, State of California. California, Department of Health Services, 1987.

[2] Davey, E. W., M. J. Morgan, et al., A biological measurement of copper complexation capacity of seawater. Limnology and Oceanography 18, pp 993-997, 1973.

[3] Gillespie, P. A. and R. F. Vaccaro, A bacterial bioassay for measuring the copper-chelation capacity of seawater. Limnology and Oceanography 23, pp 543-548, 1978.

[4] Brierley, J. A., C. L. Brierley, et al. AMT-Bioclaim: a new waste water treatment and metal recovery technology. Process Metallurgy 4, pp 291304, 1986.

[5] Holan, Z. R., B. Volesky, et al. Biosorption of cadmium by biomass marine algae. Biotechnology \& Bioengineering 41, pp 819-825, 1993.

[6] Stumm, W. and J. J. Morgan, Aquatic chemistry: chemical equilibria and rates in natural waters, John Wiley \& Sons, Inc., 1996.

[7] Institute of Medicine, Copper. Dietary reference intakes: vitamin A, vitamin $\mathrm{K}$, arsenic, boron, chromium, copper, iodine, iron, manganese, 
molybdenum, nickel, silicon, vanadium, and zinc. Food and Nutrition Board, National Academy Press, Washington, DC, pp. 224-257, 2002.

[8] Uriu-Adams, J.Y. and Keen, C.L., Copper, oxidative stress, and human health, Molecular aspects of Medicine 26, pp 268-298, 2005.

[9] Davanzo, F., Settimi, L., Faraoni, L., Maiozzi, P., Travaglia, A., Marcello, I. Agricultural pesticide-related poisonings in Italy: cases reported to the Poison Control Centre of Milan in 2000-2001. Epidemiol. Prev. 28, pp 330-337, 2004.

[10] Srivastava, A., Peshin, S.S., Kaleekal, T., Gupta, S.K., An epidemiological study of poisoning cases reported to the National Poisons Information Centre, All India Institute of Medical Sciences, New Delhi., Hum. Exp. Toxicol. 24, 279-285, 2005.

[11] World Health Organization, IPCS Environmental Health Criteria 200, Copper, World Health Organization, Vammala Finland, 1998.

[12] Bailey, S. E., T. J. Olin, et al. A review of potentially low-cost sorbents for heavy metals, Water Research 33(11), pp 2469-2479, 1999.

[13] Sunda, W. G. and P. J. Hanson, Chemical modeling in aqueous systems, Washington, American Chemical Society, 1979.

[14] Camusson, M., G. Tartari, et al. Measurement and prediction of copper ion activity in Lake Orta, Italy, Environmental Science and Technology, 25(4), pp 678-683, 1991.

[15] Xue, H. and W. G. Sunda, Comparison of $\left[\mathrm{Cu}^{2+}\right]$ measurements in lake water determined by ligand exchange and cathodic stripping voltammetry and by ion-selective electrode, Environmental Science and Technology 31, pp 1902-1909, 1997.

[16] Westall, J., Adsorption Mechanisms in Aquatic Surface Chemistry, New York, John Wiley and Sons, 1987.

[17] Chau, Y. K. and K. L. S. Chan, Determination of labile and strongly bound metals in lake water, Water Research 8, pp 383-388, 1974.

[18] Ramamoorty, S. and D. J. Kushner, Heavy metals binding component of river water, Fisheries Research Board of Canada, 32, pp 1755-1766, 1975.

[19] Rifkind, J. M., Y. A. Shin, et al. (1976). Cooperative disordering of singlestranded polynucleotides through copper crosslinking, Biophysics, 15(10), pp 1879-1902, 1976.

[20] Bermingham-McDonogh, O., D. M. De Freitas, et al., Reduced anionbinding affinity of copper, zinc superoxide dismutases chemically modified at arginine, Biochemical and Biophysical Research Communications, 108(4), pp 1376-1382, 1982.

[21] Luo, Y., Copper Species in Freshwater, unpublished MSc thesis, University of Otago, Dunedin, New Zealand, 2004.

[22] Sander, S., J. P. Kim, et al. Effect of UVB Irradiation on Cu2+-Binding Organic Ligands and $\mathrm{Cu}^{2+}$ Speciation in Alpine Lake Waters of New Zealand, Environmental Chemistry 2(1), pp 56-62, 2005.

[23] Blaedel, W. J. and D. E. Dinwiddie, Behaviour of a micro flow through copper ion-selective electrode system in the millimolar to submicromolar concentration range, Analytical Chemistry, 47(7): 1070-1073, 1975. 
[24] Avdeef, A., J. Zabronsky, et al., Calibration of Copper Ion Selective Electrode Response to pCu 19, Analytical Chemistry, 55(5), pp 298-304, 1983.

[25] Djati Utomo, H. Adsorption of Heavy Metals by Waste Tea and Coffee Residues, PhD thesis, University of Otago, Dunedin, New Zealand, 2006.

[26] Liu, X., J.-k. Kim, et al. Tannic Acid Stimulates Glucose Transport and Inhibits Adipocyte Differentiation in 3T3-L1 Cells, Journal of Nutrition 135(2), pp 165-171, 2005. 